\title{
SAR data for the analysis of forest features: current Brazilian experiences
}

(doi:10.4136/ambi-agua.9)

\section{João Roberto dos Santos; Fábio Furlan Gama; Fábio Guimarães Gonçalves}

\author{
National Institute for Space Research (INPE ) \\ São José dos Campos - SP, Brasil \\ \{jroberto, fabiogg\}@dsr.inpe.br; fabio@dpi.inpe.br
}

\begin{abstract}
This article presents some applications of airborne polarimetric and/or interferometric microwave data to improve the knowledge of forest structures. Three airborne SAR (Synthetic Aperture Radar) experiments were done in the Amazon tropical forest: (a) to study the spatial distribution of very large trees (VLTs) in the primary forest using local maximum filtering and a series of Markov processes; (b) to model the estimation of biomass variations in primary and secondary forests; (c) to analyze the retrieval of timber volume over selective logging areas. Another experiment (d) was to investigate the relation among SAR data and the volumetric configuration in stands of Eucalyptus sp. done by an airborne SAR imaging mission in SE-Brazil. To perform the objectives (b), (c) and (d) we carry out regression techniques, using variables got from multipolarimetric and/or interferometric SAR attributes and biophysical parameters from the forest cover. All data from the experiments were calibrated radiometrically to extract information during digital processing, besides an exhaustive field survey which was done simultaneously to SAR imaging, to know the physiognomy/structure of forest typology and to support the models produced for each case. The results of this series of experiments show advances at the techniques to treat SAR data, focusing on models of stand architecture and forest stock density. This will be helpful to increase the regional inventory and surveying procedures of forest conversion in the Brazilian territory in the near future.
\end{abstract}

Keywords: forest structure; SAR; forest inventory; remote sensing; tropical forest; Eucalyptus sp.; forest modeling.

\section{Dados SAR para análise de parâmetros estruturais florestais: experiências brasileiras atuais}

\section{RESUMO}

Este artigo apresenta alguns resultados da aplicação de dados polarimétricos e/ou interferométricos de radar aerotransportado no aprimoramento do conhecimento da estrutura florestal. Três experimentos científicos com radar de abertura sintética (SAR) foram realizados na floresta tropical Amazônica, tendo como linhas investigativas: (a) estudar a distribuição espacial de árvores de grande porte (Very Large Trees) em áreas de floresta primária, utilizando para tal, técnicas de filtragem de máximas locais (LM) e de processos de Markov; (b) modelar a estimativa de biomassa e suas variações em áreas de floresta primária e secundária; (c) estimar o volume de madeira em áreas de floresta tropical sob regime de exploração madeireira. Um outro experimento (d) foi investigar a relação dos dados SAR e a configuração volumétrica em povoamentos de Eucalyptus sp., cuja missão de imageamento SAR aerotransportado foi recentemente conduzida na região sudeste do Brasil. Os objetivos 
(b), (c) e (d) foram investigados por meio de técnicas de regressão, empregando variáveis derivadas de atributos multi-polarimétricos e/ou interferométricos SAR versus aquelas derivadas de parâmetros biofísicos da cobertura florestal. Todos os experimentos acima mencionados tiveram seus dados devidamente calibrados radiometricamente para extração de informações no processamento digital, além de exaustivo trabalho de campo, simultâneo ao imageamento SAR, para o conhecimento fisionômico-estrutural da tipologia florestal e validação dos modelos gerados em cada caso. Os resultados dessa série de experimentos mostram avanços nas técnicas de tratamento dos dados SAR, focalizando na construção de modelos da arquitetura do povoamento e no estoque de biomassa florestal. Isso será muito útil para melhorar os procedimentos de inventário regional e monitoramento das conversões de floresta no território brasileiro.

Palavras-chave: estrutura florestal; SAR; inventário florestal; sensoriamento remoto; floresta tropical; Eucalyptus sp.; modelagem florestal.

\section{INTRODUCTION}

The multipolarimetric and/or interferometric approach, rather than using a single frequency radar, allows details to be obtained about three-dimensional forest structures of the scattering targets under study (Kasischke et al., 1997 and Treuhaft et al., 2004). Using this approach it is possible to set up relationships about biomass and volumetric contents of natural and planted forest stands. Some experiments using SAR data for mapping and forest inventory were conducted in different sites, as described below:

- the spatial distribution of very large trees (VLTs) in an Amazon primary forest was extracted from a digital model of interferometric height by an approach of local maximum filtering;

- the radar backscatter values drawn from specific polarizations were combined with an interferometric height model (derived from X-and P-bands) to settle a statistical relationship with forest aboveground biomass;

- a combination of multipolarimetric variables at amplitude and backscatter modes, derived from L-band, allows characterization those areas of forest with timber logging, as well as modeling estimating the commercial timber volume of the forest stands;

- multivariate analysis was used to produce a model to estimate forest volume of Eucalyptus sp. stands, associating the volumetric scattering (VSI), polarimetric coherence in P-band, as well as the interferometric height from DEM of X- and P-bands.

The studies are representative of knowledge of SAR (Synthetic Aperture Radar) data processing for forestry issues. To briefly introduce a reader on this subject, including ideas and applications of radar data in forestry, refer to Ulaby and Elachi (1990), Beaudoin et al. (1994), Rauste et al. (1994), Henderson and Lewis (1998), and Coops (2002). These authors studied multipolarimetric SAR backscatter for discriminating forest types, discussing those aspects of scattering and attenuation of SAR signals at different frequencies interacting with structural vegetation features. Further, Wegmüller and Werner (1997), Baltzer (2001), Neeff et al. (2005a), Kugler et al. (2006), Treuhaft et al. (2006) discuss the contribution of the interferometric mode to estimate biophysical parameters in forest areas. Pope et al. (1994) developed indices based on ratios and normalized differences of multipolarimetric data, which can be related to certain characteristics of vegetation cover, such as e.g. biomass index $\left[\mathrm{BMI}=\left(\sigma_{\mathrm{HH}}^{\mathrm{o}}+\sigma_{\mathrm{VV}}^{\mathrm{o}}\right) / 2\right]$, canopy structure index [CSI $\left.=\sigma_{\mathrm{VV}}^{\mathrm{o}} /\left(\sigma_{\mathrm{VV}}^{\mathrm{o}}+\sigma_{\mathrm{HH}}^{\mathrm{o}}\right)\right]$, volume scattering index $\left[\mathrm{VSI}=\sigma_{\mathrm{HV}}^{\mathrm{o}} /\left(\sigma_{\mathrm{HV}}^{\mathrm{o}}+\mathrm{BMI}\right)\right]$, applied to tropical forests in Central America. 
Power spectrum analysis was used for the analysis of spatial forest features (canopy structure and distances between major tree individuals) from airborne SAR (X-band) data in the Brazilian Amazon (Neeff et al., 2005b). Hoekman and Quiñones (2000), Hawkins et al. (2000), and Santos et al. (2002; 2003) specifically estimated forest biomass, and discussed backscatter saturation caused by the high-density of tropical forests.

\section{THE AIRBORNE SAR CAMPAIGNS}

Two early studies were conducted around the Tapajós National Forest, in the Brazilian Amazonia (W $54^{\circ} 53^{\prime}$ to $55^{\circ} 06^{\prime}$ and $\mathrm{S} 03^{\circ} 03^{\prime}$ to $03^{\circ} 12^{\prime}$ ). The airborne SAR data were collected by the AeS-1 sensor system (Germany), which makes use of interferometric technology. It runs on X-band $(\lambda=3 \mathrm{~cm})$ with one polarization $(\mathrm{HH})$ and, fully polarimetric on P-band ( $\lambda=72 \mathrm{~cm}$; depression angle $\sim 45^{\circ}$; range resolution $1.5 \mathrm{~m}$; azimuth resolution $0.7 \mathrm{~m}$ for one-look slant range image).

The third study was also performed in the Tapajós region, but with data from SARR99B from SIPAM, onboard of an EMB-145 aircraft, in L-band $\mathrm{HH}, \mathrm{HV}$ and VV polarization, with $10 \mathrm{~m}$ spatial resolution. This mission was conducted within the technical cooperation between INPE/Brazilian Space Agency (AEB) and the German Aerospace Center (DLR) for analysis of construction of spaceborne radar (MAPSAR).

The fourth study was carried out recently in the Rio Paraíba Valley region (W $45^{\circ} 23^{\prime}$ to $45^{\circ} 25^{\prime}$ and $\mathrm{S} 22^{\circ} 54^{\prime}$ to $22^{\circ} 55^{\prime}$ ), São Paulo State, provided airborne SAR data over reforested area with Eucalyptus sp., collected by the OrbiSAR-1 system (OrbiSat da Amazônia S.A.). It performs at X- band with $\mathrm{HH}$ polarization and $1 \mathrm{~m}$ of resolution, including also, the full polarimetric P-band (range and azimuth resolution of $2 \mathrm{~m}$ ), both with an incidence angle of $\sim 45^{\circ}$.

During all missions mentioned, corner reflectors were installed in the areas researched and used as references for the polarimetric and radiometric calibrations and/or also, as references for the interferometric phase analysis. A field survey was done simultaneously to the airborne SAR experiments that included several observation plots of land cover/land use classes and of sites of forest inventory, all georeferenced.

\section{THE SAR INTERFEROMETRIC DATA FOR MODELING SPATIAL TREE PATTERNS}

Of particular ecological significance for the carbon regime, the conditions of natural regrowth, and the patterns of the species diversity and distributions is assigned to very large trees (VLTs). Thus, the basic idea of this work is that trees with dominant crown position are VLTs, that therefore appearing in radar interferometric data, containing added information on the three-dimensional structure of the scattering targets of the area under study (Neeff et al., 2005a). Generally, the P-band radar signal penetrates a forest structure, to the ground surface, and it can be used for interferometric generation of a Digital Elevation Model (DEM). The Xband is reflected by canopy, and so the forest canopy is related to a Digital Surface Model (DSM). In this study, both models were thoroughly calibrated and had a spatial resolution (pixel size) of $2.5 \mathrm{~m}$. The difference between both models represents the height of vegetation, called "interferometric height" (hint). The application of local maximum (LM) filtering (Wulder et al., 2000) to a digital height model, directly makes use of the three-dimensional canopy structure of forest, where the areas of maximum vegetation height coincide with the tops of crowns. In this investigation, LM filtering, using circular windows with a radius of 
three pixels $(7.5 \mathrm{~m})$ were used focusing on three sample blocks (100 ha each) of undisturbed primary forest.

The spatial point patterns (stochastic process) of very large trees in the primary forest were modeled by a Markov point process models (Cressie, 1993), which could represent repulsive interactions of the structure that leads to a regular point pattern. In this case, the Complete Spatial Randomness model (CSR), Simple Sequential Inhibition model (SSI), Strauss process (Str), a Strauss Hard-Core model (StrHC) and a Soft-Core process (SC) were used.

Considering various specific results, it is possible to affirm that: the intensities of the VLT point patterns, considering all three blocks, are estimated to be $\sim 7$ trees/ha, and the mean distance of these trees is around $24 \mathrm{~m}$. The Soft-Core (SC) pair potential function (Figure 1) is a model that fits more significantly the data of these three blocks, where the empirical K-function remains within the confidence intervals from a Monte-Carlo simulation over the whole range of distances (Neeff et al., 2005a). Locations of very large trees are almost independent at distances above ca. $\sim 29 \mathrm{~m}$, also, the repulsive dependence is shown to decrease smoothly with distance.

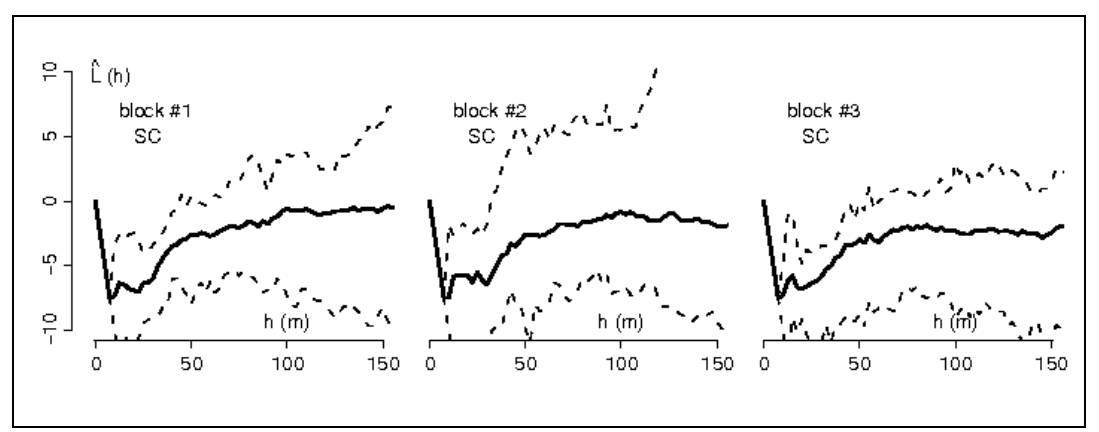

Figure 1. K-functions of the final model in all three sample blocks. Solid lines correspond to empirical K-functions, dotted lines are confidence intervals from Monte-Carlo simulations $(\alpha=0.1, \mathrm{n}=20)$, given the fitted soft-core model (SC). All functions are transformed for display purposes by the theoretical K-function under CSR to $\mathrm{L}(\mathrm{h})=\sqrt{\mathrm{K}_{\mathrm{CSR}} / \pi-\mathrm{h}}$.

Source: (Neeff et al., 2005a).

\section{THE INTERFEROMETRIC AND POLARIMETRIC SAR DATA FOR ABOVEGROUND BIOMASS ESTIMATION}

In previous studies, the stock of aboveground standing biomass of primary and secondary forests in the Tapajós region was related to backscatter values at P-band. Using logarithmic and polynomial functions $\mathrm{R}^{2}$ values $<0.70$ were obtained, with better data fitting at the $\mathrm{HH}$ polarization, when compared with HV and VV (Santos et al., 2003). The true ability and applicability of radar imagery may not be for biomass estimation "directly", but rather as a means to stratify forest stands along structural lines to reduce structural variation as a source of error (Coops, 2002). Considering that this fitting is not yet satisfactory for biomass estimation, it became necessary to insert the variable "interferometric height" in the modeling. So, the first methodological step was to segment the interferometric image (hint model), using a multilevel incremental algorithm (hierarchical region growth). This segmentation approach starts, according to (Sousa Jr. et al., 2003) with the image degradation (compression) in pyramid-like structural levels, where each level is represented by an average image (in this case, each pixel is formed by the average of four pixels from the image of the 
hierarchical lower level). This relation with the neighborhood is defined by the t-Student test, to which an acceptance likelihood value is established (Cook et al., 1994). In this study, six hierarchical levels were considered. After the segmentation was ended, the interferometric height value for each polygon (matching to the positioning of SAR image of each georeferenced and inventoried sample during the field survey) was extracted. These interferometric height values of primary forests and secondary succession were then integrated into $\mathrm{P}_{\mathrm{HH}}$ backscatter values, giving a biomass model, based on an adjusted equation. The thematic mapping was created sequentially with signs of biomass variations.

Because of this methodological development, the best biomass model [biomass $=44.965$ $+13.887 \times$ hint $\left.+10.556 \times \sigma^{\circ} \mathrm{Ph}\right]$ was established after comprehensive testing of a range of specific allometric equations to achieve statistically high precision in standing biomass prediction $\left(\mathrm{R}^{2}=0.89\right)$. It is important to mention that during the absolute SAR calibration at $\mathrm{P}_{\mathrm{HH}}$ band used during modeling, the values obtained varied $+/-0.77 \mathrm{~dB}$ at the four corner reflectors used as calibration references. This biomass model was set up for all forest types occurring in this area; ranging from early regrowth with biomass levels below than 5 ton/ha to primary forest with biomass levels up to 350 ton/ha. This model is linear and thus not affected by saturation of backscatter response with increasing biomass levels that has been reported as a general problem of tropical forest watching by radar. Using this biomass modeling, the stratification of homogeneous landscape units with similar biophysical characteristics was done. The error of biomass estimation, using this model is of about $15 \%$ for primary forests (Figure 2).

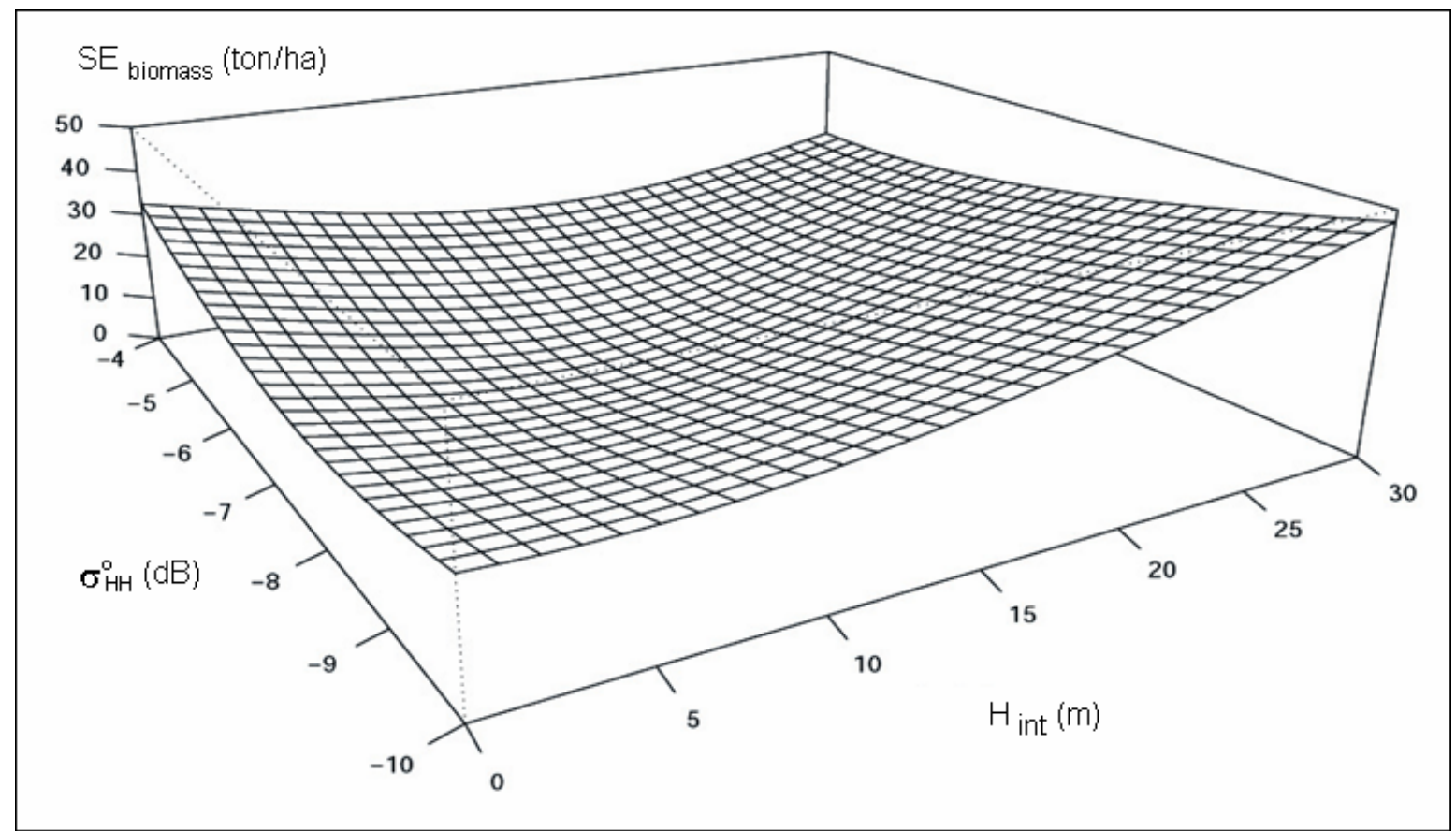

Figure 2. Variance of forest biomass estimation as a function of height interferometry and backscatter data. Source: (Santos et al., 2004).

Figure 2 plots the expected error of forest biomass prediction from radar data against the predictor variables. In multiple regression, uncertainty in predicting new observations changes with the values for the independent variables (here interferometric height and backscatter). We used the fitted regression model (presented above) for producing a surface of expected errors that would sketch the performance of the model. For this purpose, the prediction error is considered to match to the sum of the standard error of estimate and the 
squared standard error of the mean prediction, both of which can be obtained from typical regression output. The surface of prediction errors shows the uncertainties in biomass estimation increase with extreme values for interferometric height and for backscatter.

\section{THE MULTIPOLARIZED SAR DATA FOR MODELING VOLUME ESTIMATION IN FOREST WITH SELECTIVE LOGGING}

An important point to be considered in this study is that SAR-R99B data were initially calibrated to perform the modeling. The following tasks were done: 1st antenna pattern correction to remove gain variations in the range direction (Ulaby et al., 1982) by a polynomial function applied to the sum of the amplitude values; and 2nd determination of the absolute calibration constant, based on the corner reflectors placed in the area under study during the imaging campaign, to allow transforming amplitude data in backscatter values of targets, using the method of peak power (Gray et al., 1999). For the absolute SAR calibration, the average error was $-0.8443 \mathrm{~dB}$ and the standard deviation $0.18 \mathrm{~dB}$, as related to the theoretical sigma, calculated from the response of 12 corner reflectors. Mura et al. (in press) describe, with more details, the calibration approach used for the polarimetric L-band of the SAR99-R99B. Based on this calibration, the similar $\sigma^{0}(\mathrm{~dB})$ values for primary tropical forests (average $\sigma_{\mathrm{HH}}^{0}=-6.93 ; \sigma_{\mathrm{HV}}^{0}=-11.66 ; \sigma_{\mathrm{VV}}^{0}=-6.69$ ) as those from Saatchi et al. (1997), Luckman et al. (1998), Hoekman and Quiñones (2000) and Santos et al. (2002). This shows the cohesion of the SAR-R99B response if compared with those responses of other L-band systems used, at similar polarizations.

To represent the variability existing at the forest management under study, 30 sample sections of 0.2 ha size, in blocks with different exploitation ages were established. Defining these forest inventory sections was done by stratified random sampling, and the polygons were delimited and positioned by GPS and Infrared Total Station. The commercial volumetric values of samples were determined by an allometric equation, developed by Queiroz (1984) for the Tapajós National Forest. This volumetric equation, based on the random collection of 110 trees in a stand of over 170 species, was defined as [Vest $=a+b$ $\left.\left(\mathrm{DAP}^{2} . \mathrm{H}\right)\right]$. Using this allometric model, and an uncertainty of $0.5 \%$ to $0.05 \%$ according to Brown et al. (1995), the coefficient values considered were $\mathrm{a}=0.0775, \mathrm{~b}=0.518$ and $\mathrm{R}^{2}=$ 0.965 .

Multiple regression techniques were applied to derive a model for Commercial Timber Volume (VCM), using PolSAR L-band data. The model was defined by a set of explanatory variables which included the minimum, maximum, average, standard deviation and variation coefficient of amplitude and backscatter values (Henderson and Lewis, 1998), observed at the three polarizations (HH, HV and VV). Dispersion diagrams and correlation matrices were used at an exploratory analysis of the sensor data against those obtained in the field, to corroborate the need of transformations at the variables and/or to verify those which would best contribute to the model.

Table 1 shows the correlations among SAR polarimetric variables (amplitude and backscatter) and the commercial timber volume. Based on the adjusted determination coefficient criterion, the best subset of variables was the one formed by the minimum values of the interactions $\left[\sigma^{\circ}{ }_{\mathrm{HH}} * \sigma^{\circ} \mathrm{HV}\right]$ and $\left[\sigma^{\circ}{ }_{\mathrm{HH}} * \mathrm{~A}_{\mathrm{HH}}\right]$, as mentioned by Gonçalves et al. (2006). Using the statistical regression package of this model, we formed up to nine significant figures, simplified to only three significant figures. The general model is described by equation [VCM $\left.=-140+0.0928 *\left(\sigma_{\mathrm{HH}}^{\circ} \sigma^{\circ}{ }_{\mathrm{HV}}\right)-0.00268 *\left(\sigma_{\mathrm{HH}}^{\circ} * \mathrm{~A}_{\mathrm{HH}}\right)\right]$. According to Brown et al. (1995) while studying the uncertainty of measurement, typical for environmental sciences, the use of five significant figures is false and misleading. Using the adapted Levene 
test, it was verified the variance of residuals is constant at $5 \%$ significance level. During the validation process, this model was checked against independent data, with the spatialization of the timber volume estimates over 3,220ha of forest (38 blocks) checking estimated and observed values and using independent and representative blocks of the explored forest, it was shown the volume estimation error was below $20 \%$ for $80 \%$ of the samples (Figure 3 ).

Table 1. Correlation matrix between polarimetric and volume variables.

\begin{tabular}{c|c|c|c|c|c}
\hline $\begin{array}{c}\text { SAR } \\
\text { variable }\end{array}$ & $\begin{array}{c}\text { VCM } \\
\text { minimum }\end{array}$ & $\begin{array}{c}\text { VCM } \\
\text { maximum }\end{array}$ & $\begin{array}{c}\text { VCM } \\
\text { average }\end{array}$ & $\begin{array}{c}\text { Standard } \\
\text { deviation }\end{array}$ & $\begin{array}{c}\text { Variation } \\
\text { coefficient }\end{array}$ \\
\hline $\mathrm{A}_{\mathrm{HH}}$ & $0.50^{*}$ & 0.34 & 0.28 & 0.08 & -0.22 \\
$\mathrm{~A}_{\mathrm{HV}}$ & 0.33 & -0.05 & 0.22 & -0.15 & -0.32 \\
$\mathrm{~A}_{\mathrm{VV}}$ & 0.24 & 0.12 & 0.22 & 0.07 & -0.15 \\
$\sigma_{\mathrm{HH}}^{\mathrm{o}}$ & $0.49^{*}$ & 0.28 & 0.24 & -0.30 & -0.22 \\
$\sigma_{\mathrm{HV}}^{\mathrm{o}}$ & $0.36^{*}$ & -0.07 & 0.23 & -0.31 & 0.15 \\
$\sigma_{\mathrm{VV}}^{\mathrm{o}}$ & 0.24 & 0.05 & 0.20 & -0.15 & -0.23 \\
\hline
\end{tabular}

(*) Significant correlations values at $5 \%$ significance level.

Source: Gonçalves et al. (2006).

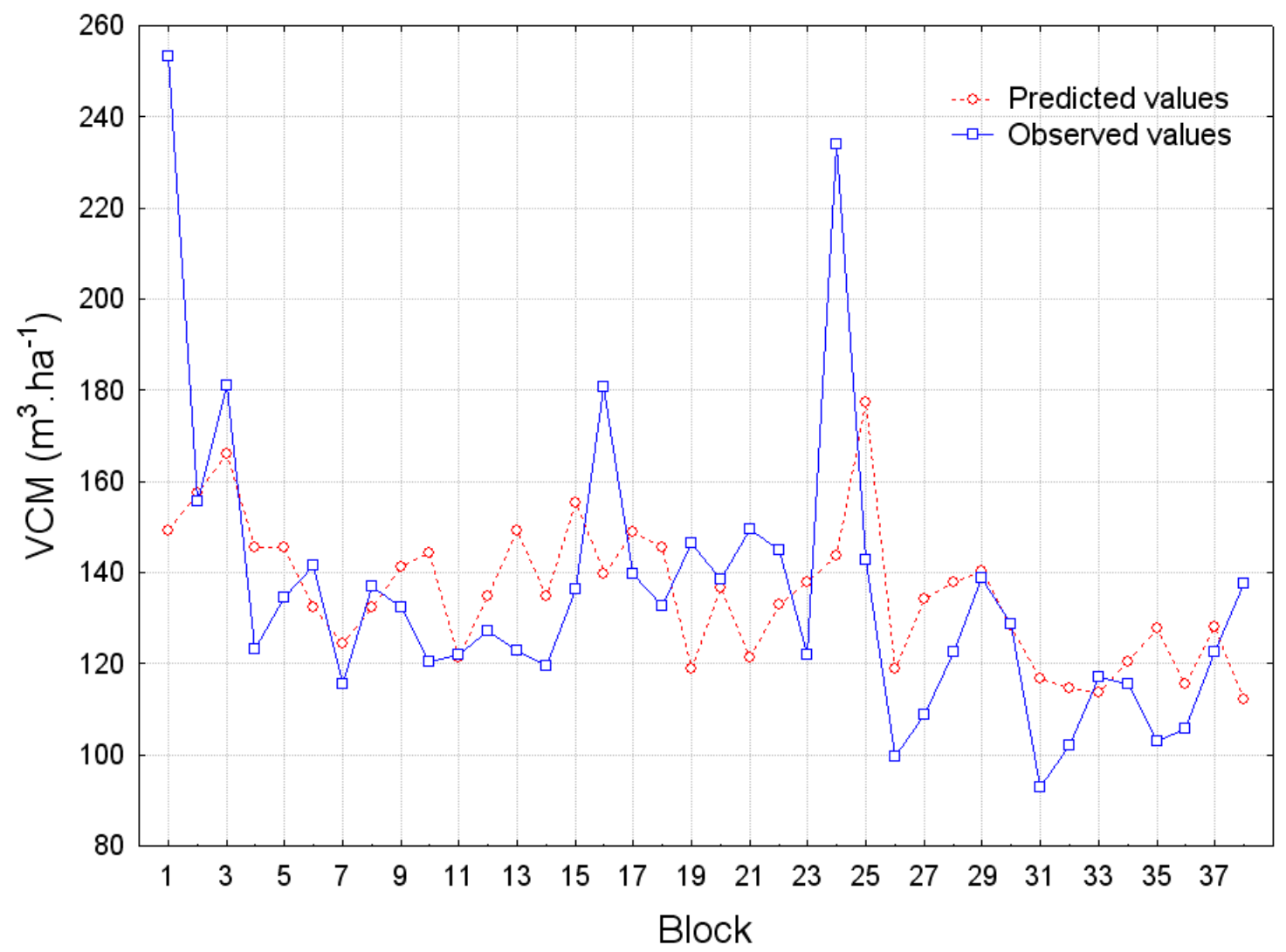

Figure 3. Comparison among estimated volume by a regression model and field measured volume in the sampling blocks of tropical forest under timber exploitation.

From the first results obtained with the amplitude and backscatter SAR values, we are doing analysis which allow to describe the polarimetric characteristics of forest targets from a new series of features which include: the phase difference $(\Delta \varphi)$, and the polarimetric coherence $(\gamma)$ among polarizations HH and VV, described by Henderson and Lewis (1998); the entropy $(\mathrm{H})$, the anisotropy $(\mathrm{A})$ resulting from the decomposition by autovectors from the coherence matrix (Cloude and Pottier, 1996) and the components of volumetric scattering 
$(\mathrm{Pv})$, double-bounce $(\mathrm{Pd})$ and superficial $(\mathrm{Ps})$, resulting from the incoherent decomposition of the covariance matrix (Freeman and Durden, 1998). To refine the models generated, some statistical procedures such as the diagnosis of multicolinearity, analysis of outliers and residuals (Neter et al., 1996; Shapiro et al., 1968) are part of the methodological approach, at the interaction of SAR and field survey data.

\section{THE INTERFEROMETRIC AND POLARIMETRIC SAR DATA FOR VOLUMETRIC MODELING OF EUCALYPTUS SP. STANDS}

To allow modeling, the OrbiSAR-1 data (X- and P-bands) was initially calibrated radiometrically from several corner reflectors, scattered on strategic places, along the imaging SAR lines. Therefore, the antenna pattern correction, the absolute calibration were done, and the polarimetric calibration to minimize the distortions imposed by the PolSAR system in the scattering matrix (cross talk and channel imbalance), using the method proposed by Quegan (1994).

The Eucalyptus volume model was estimated by linear regression modeling between by a field inventory data and the interferometric and radiometric SAR data. This study area in Pindamonhangaba/SP region was featured by a 6.1 years old Eucalyptus saligna culture. The field inventory data was obtained by measurement of the DBH and height of all trees in 23 independent stands of $\sim 400 \mathrm{~m}^{2}$ each, these data were used to calculated the stands volume values using form factor. Simultaneously some topographic profiles were carried out using Infrared Total Station in the same stands, for the interferometric quality DEM analysis.

To select the variables to the regression model the Stepwise, $C p, R^{2}$ and $R^{2}$ a were used, as well as the Cook's distance to find the outliers cases. The Levene's method was used to corroborate the homoscedastic behavior of regression residues.

The comparison of the topographic surveying results and the Digital Elevation Model (DEM) by interferometry in P-band showed that a better correlation was obtained in the $\mathrm{HH}$ polarization, if compared with the result of other polarizations to describe the ground height. This result pointed out the diameter of the trees didn't influence the P-band interferometry, and only the interaction with the ground forest has happened. The DEM from interferometry in X-band followed the tree heights, when compared with the inventory data (Gama et al., 2006).

The SAR radiometry, and the volumetric scattering index (VSI) were also tested, but they weren't significant statistically for the timber volume model, so these variables were discarded for the regression model. Particularly the X-band radiometry had a significant capacity to discriminate differences in stands of Eucalyptus formed by clones; this response of the X-band, was expected because of shorter wavelength being attenuated by foliage in the canopy, making discrimination from lower parts of the forest stand more difficult (Coops, 2002). It was also expected that both indices VSI (measure of the depolarization of the linearly polarized incident radar angle, which expresses the canopy thickness or density) and CSI (measure of the relative importance of vertical versus horizontal structure in the forest cover), set up by Pope et al. (1994), would allow an improvement from the performance of the models, easing a physical explanation in the set of SAR variables for the volumetric estimation, but in fact it did not occur.

Similar to the SAR radiometry, the interferometric coherence in P- and X-band presented low sensitivity to the trees volume; however, the X-band coherence had also a significant ability to discriminate species differences in clones' stands.

The final volume regression model pointed out the logarithm of interferometric height (Log hint) (difference between interferometric DEM in X- and P-bands) was the most relevant SAR variable to this model. The reason for this behavior was due the fact the 
Eucalyptus trees structure are mainly cylindrical and vertically oriented, with a small crown, whose height is related to the timber volume, so the regression model using the interferometric height could estimate the volume.

The volume model earned $83.53 \%$ for the determination coefficient, with one outlier case. The graphics of the Figure 4a picture the model behavior, of the final model equation: Volume $=-314.035+427.946$ Log hint.

The graphics of the Figure $4 \mathrm{~b}$ shows the model results in comparison with the inventory data, and the differences of these data. The biggest difference occurred in the stand 4 due this case was considered as outlier in the regression and was not used to build the regression model.

Comparing the predicted results with the inventory data, noticed that some cases showed differences beyond the standard deviation of the data, because of the outlier that was discarded in the regression and the presence of gaps in the stands between 6.9 to $60.3 \%$, that prejudiced the interferometric height by the SAR sensor.

For the model validation the criterion PRESS (PREdiction Sum of Squares) and SSE (Sum of Squares Errors) were used, the values were similar, that allowed to use the MSE (Mean Squared Errors) and pointed out the prediction errors. The MSE for the volume regression model presented $1,126.6$ of value, that represented $33.56 \mathrm{~m}^{3} / \mathrm{ha}$, or $10.55 \%$ of prediction error if compared with maximum stands volume.

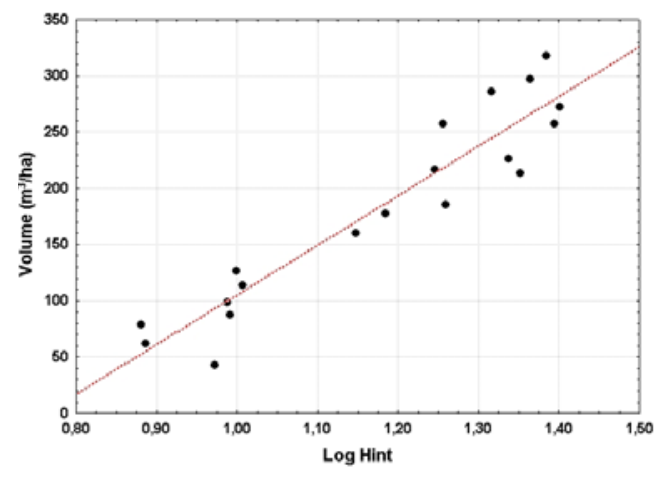

a)

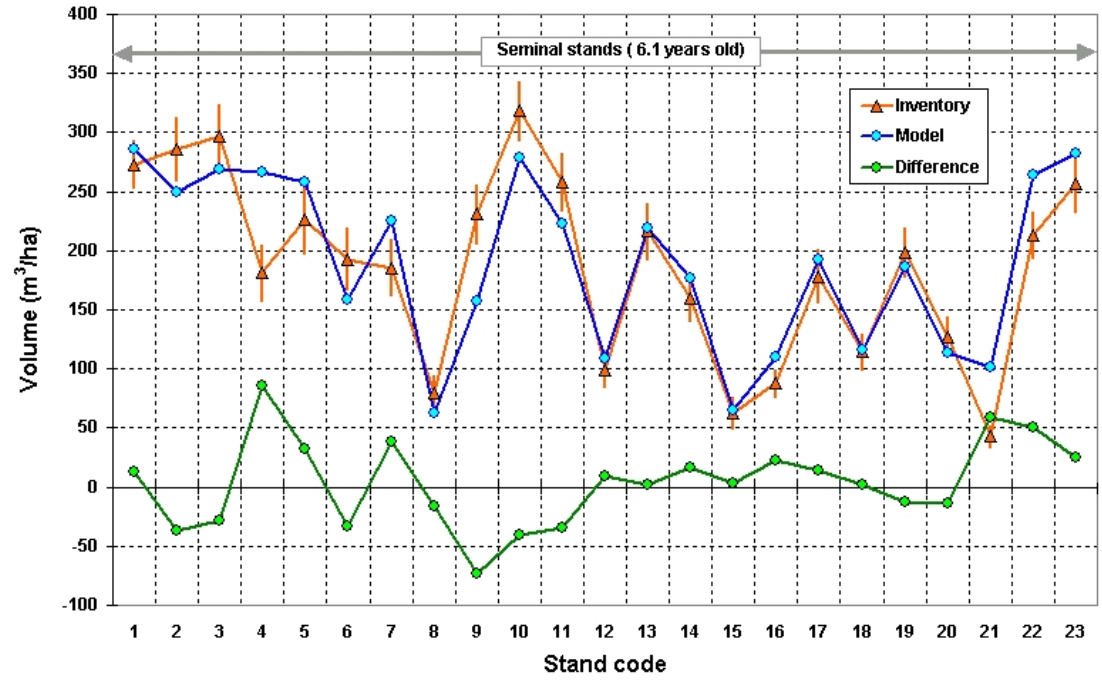

b)

Figure 4. a) Volume regression model; b) Response of volumetric distribution of the Eucalyptus $s p$. stands based on the interferometric height logarithm.

\section{CONCLUSIONS}

Based on the three experiments, we concluded that:

- The very large trees with their dominant position in the forest can be identified by interferometric SAR technology drawn from X- and P-band, in ground resolution which is compatible with the object under study. The analysis and modeling of the spatial point patterns of very larges trees are possible by local maximum filtering technique and series of Markov process;

- Biomass estimates, when incorporating interferometric height and backscatter data, provide a higher accuracy to the estimation model. A good calibration of digital surface model and digital elevation model are necessary to create an acceptable image of interferometric height; 
- The model selected to estimate the commercial volume of forest under timber exploitation, which uses the variables amplitude and backscatter at L-band, pointed out consistency for predicting the estimation, whose performance was proved by a large independent sampling;

- Considering these preliminary results, the interferometric products (Log hint) have a strong relationship with the Eucalyptus volume, mainly because this forest has a well defined and small understory, and the species under study has a small canopy despite its great height, and the volume is related to the height of stands.

The forest structure has a significant effect on the radar signal and, often, it is the overwhelming variable in controlling the type and quantity of backscatter observed in forest environments. Advances in analysis of SAR data, focusing in models of stand architecture, stocking density and picture forest growth will be helpful to increase regional inventory and surveying procedures of forest change-over in the Brazilian territory in the near future.

\section{ACKNOWLEDGEMENT}

The authors acknowledge CNPq and CAPES for the research grants; the 5th Divisão de Levantamento do Exército, 8th BEC (Brazilian Arm), IBAMA/MMA, LBA office (SantarémPA), Nobrecel Celulose e Papel S.A., Diâmetro Biometria e Inventário Florestal, ORBISAT da Amazônia S.A. for the logistic support. These studies are a contribution to the "Science and Technology for the Management of Ecosystems" Program, from the Brazilian Ministry for Science and Technology (MCT).

\section{REFERENCES}

BALTZER, H. Forest mapping and monitoring with interferometric synthetic aperture radar (INSAR). Progress in Physical Geography, London, v. 25, n. 2, p. 159-177, 2001.

BEAUDOIN, A.; LE TOAN, T.; GOZE, S.; NEZRI, E.; LOPEZ, A.; MOUGIN, E. et al. Retrieval of forest biomass from SAR data. International Journal of Remote Sensing, London, v. 15, n. 14, p. 2777-2796, 1994.

BROWN, I. F.; TURCQ, B.; ALECHANDRE, A. Teaching concepts of accuracy, precision, and opportunity cost in environmental sciences: arms, legs, and significant figures. Ciência e Cultura, Campinas, v. 47, n. 1/2, p. 41-44, 1995.

CLOUDE, S. R.; POTTIER, E. A review of target decomposition theorems in radar polarimetry. IEEE Transactions on Geoscience and Remote Sensing, Piscataway, v. 34, n. 2, p. 498-518, 1996.

COOK, R.; Mc CONNELL, L.; OLIVER, C. J.; WELBOURNE, E. MUM (Merge Using Moments) segmentation for SAR images. In: EUROPTO SAR DATA PROCESSING FOR REMOTE SENSING - SPIE, 1994, Rome. Proceedings... Rome: [S.n.], 1994. p. 92-103. vol. 2316.

COOPS, N. C. Eucalyptus forest structure and synthetic aperture radar backscatter: a theoretical analysis. Trees, Berlin, v. 16, n. 1, p. 28-46, 2002.

CRESSIE, N. A. Statistics for spatial data. New York: John Wiley \& Sons, 1993. 900p. 
FREEMAN, A.; DURDEN, S. L. A three-component scattering model for polarimetric SAR data. IEEE Transactions on Geoscience and Remote Sensing, Piscataway, v. 36, n. 3, p. 963-973, 1998.

GAMA, F. F.; SANTOS, J. R.; MURA, J. C.; RENNÓ, C. D. Estimation of biophysical parameters in the Eucalyptus stands by SAR data. Ambiência, Guarapuava, v. 2, n. 1, p. 29-42, 2006.

GONÇALVES, F. G.; SANTOS, J. R.; LOPES, A. L. B. Análise de dados SAR para estimativa volumétrica da floresta tropical em regime de exploração madeireira. In: SEMINÁRIO DE ATUALIZAÇÃO EM SENSORIAMENTO REMOTO E SISTEMAS DE INFORMAÇÕES GEOGRÁFICAS APLICADOS À ENGENHARIA FLORESTAL, 7., Curitiba, 2006. Anais... Curitiba: [S.n.], 2006. p. 42-48.

GRAY, A. L.; VACHON, P. W.; LIVINGSTONE, C. E.; LUKOWSKI, T. L. Synthetic Aperture Radar calibration using reference reflectors. IEEE Transactions on Geoscience and Remote Sensing, Piscataway, v. 28, n. 3, p. 374-383, 1990.

HAWKINS, R. K.; ATTEMA, E.; CRAPOLICCHIO, R.; LECOMTE, P.; CLOSA, J.; MEADOWS, P. J. et al. Stability of Amazon backscatter at C-band: spaceborne results from ERS-1/2 and Radarsat-1. In: SAR WORKSHOP: CEOS COMMITTEE ON EARTH OBSERVATION SATELliTeS, 1999, Toulouse. Proceedings... Paris: European Space Agency, 2000. p. 99-108.

HENDERSEN, F. M.; LEWIS, A. J. Radar fundamentals: the geoscience perspective. In: RYERSON, R. A. (Ed.). Principles \& applications of imaging radar: manual of remote sensing. 3. ed. New York: John Wiley \& Sons, 1998. p. 131-181.

HOEKMAN, D. H.; QUINONES, M. J. Land cover type and biomass classification using AirSAR data for evaluation of monitoring scenarios in the Colombian Amazon. IEEE Transactions Geoscience and Remote Sensing, Piscataway, v. 38, n. 2, p. 685-696, 2000.

KASISCHKE, E. S.; MELACK, J. M.; DOBSON, M. C. The use of imaging radar for ecological applications: a review. Remote Sensing of Environment, New York, v. 59, n. 2, p. 141-156, 1997.

KUGLER, F.; PAPATHANASSIOU, K. P.; HAJNSEK, I. Forest height estimation over tropical forest by means of polarimetric SAR interferometry. In: SEMINÁRIO DE ATUALIZAÇÃO EM SENSORIAMENTO REMOTO E SISTEMAS DE INFORMAÇÕES GEOGRÁFICAS APLICADOS À ENGENHARIA FLORESTAL, 7. 2006, Curitiba. Anais... Curitiba: [S.n.], 2006. p. 504-512.

LUCKMAN, A.; BAKER, J.; HONZÁK, M.; LUCAS, R. Tropical forest biomass density estimation using JERS-1 SAR: Seasonal variation, confidence limits, and application to image mosaics. Remote Sensing of Environment, New York, v. 63, n. 2, p. 126-139, 1998 .

MURA, J. C.; CORREIA, A. H.; HONDA, P. Calibração preliminar dos dados SAR polarimétricos em banda $\mathrm{L}$ do sensor R99B do CENSIPAM. In: SIMPÓSIO 
BRASILEIRO DE SENSORIAMENTO REMOTO - SBSR, 13., 2007, Florianópolis. Anais... São José dos Campos: INPE, in press.

NEEFF, T.; BIGING, G. S.; DUTRA, L. V.; FREITAS, C. C.; SANTOS, J. R. Modeling spatial tree pattern in the Tapajós forest using interferometric height. Revista Brasileira de Cartografia, Presidente Prudente, ${ }_{2}$. 57, n. 1, p. 1-6, 2005 a.

NEEFF, T.; DUTRA, L. V.; SANTOS, J. R.; FREITAS, C. C.; ARAUJO, L. S. Power spectrum analysis of SAR data for spatial forest characterization in Amazonia. International Journal of Remote Sensing, London, v. 26, n. 13, p. 2851-2865, 2005b.

NETER, J.; KUTNER, M. H.; NACHTSHEIM, C. J.; WASSERMAN, W. Applied linear statistical models 4 ed. Boston: McGraw-Hill, 1996. 1408p.

POPE, K. O.; REY-BENAYAS, J. M.; PARIS, J. F. Radar remote sensing of forest and wetland ecosystems in Central American Tropics. Remote Sensing of Environment, New York, v. 2, n. 48, p. 205-219, 1994.

QUEGAN, S. A unified algorithm for phase and cross-talk calibration of polarimetric data theory and observations. IEEE Transactions on Geoscience and Remote Sensing, Piscataway, v. 32, n. 1, p. 89-99, 1994.

QUEIROZ, W. T. Análise de fatores pelo método da máxima verossimilhança: aplicações ao estudo da estrutura de florestas tropicais. 1984, 112f. Tese (Doutorado em Agronomia) - Escola Superior de Agricultura Luiz de Queiroz, Universidade de São Paulo, Piracicaba, 1984.

RAUSTE, Y.; HAME, T.; PULLIAINEN, J.; HEISKA, K.; HALLIKAINEN, M. Radar based forest biomass estimation. International Journal of Remote Sensing, London, v. 15, n. 14, p. 2797-2808, 1994.

SAATCHI, S. S.; SOARES, J. V.; ALVES, D. S. Mapping deforestation and land use in Amazon rainforest by using SIR-C Imagery. Remote Sensing of Environment, New York, v. 59, n. 2, p. 191-202, 1997.

SANTOS, J. R.; FREITAS, C. C.; ARAUJO, L. S.; DUTRA, L. V.; MURA, J. C.; GAMA, F. F. et al. Airborne P-band SAR applied to the aboveground biomass studies in the Brazilian tropical rainforest. Remote Sensing of Environment, New York, v. 87, n. 4, p. 482-493, 2003.

SANTOS, J. R.; NEEFF, T.; ARAUJO, L. S.; GAMA, F. F.; DUTRA, L. V.; SOUSA JR. M. A. Interferometria SAR (bandas X e P) na estimativa de biomassa florestal. Série em Ciências Geodésicas, Curitiba, v. 4, p. 161-175, 2004.

SANTOS, J. R.; PARDI LACRUZ, M. S.; ARAUJO, L. S.; KEIL, M. Savanna and tropical rainforest biomass estimation and spatialization using JERS-1 data. International Journal of Remote Sensing, London, v. 23, n. 7, p. 1217-1229, 2002.

SHAPIRO, S. S.; WILK, M. B.; CHEN, H. J. A comparative study of various tests of normality. Journal of the American Statistical Association, Alexandria, v. 63, n. 324, p. 1343-1372, 1968. 
SOUSA JR., M. A.; DUTRA, L. V.; FREITAS, C. C. Desenvolvimento de um segmentador incremental multi-nível (SIM) para imagens ópticas e de radar. In: SIMPÓSIO BRASILEIRO DE SENSORIAMENTO REMOTO, 11., 2003, Belo Horizonte. Anais.... São José dos Campos: INPE, 2003. p. 2293-2300.

TREUHAFT, R. N.; CHAPMAN, B.; DUTRA, L. V.; GONÇALVES, F. G.; SANTOS, J. R.; MURA, J. C. et al. Estimating 3-dimensional structure of tropical forest from radar interferometry. Ambiência, Guarapuava, v. 2, n. 1, p. 111-119, 2006.

TREUHAFT, R. N.; LAW, B. E.; ASNER, G. P. Forest attributes from radar interferometric structure and its fusion with optical remote sensing. BioScience, Washington, v. 54, n. 6, p. 561-571, 2004.

ULABY, F. T.; ELACHI, C. Radar polarimery for geoscience applications. Norwood: Artech House, 1990. 365p.

ULABY, F. T.; MOORE, R. K.; FUNG, A. K. Microwave remote sensing active and passive. Norwood: Artech House, 1982. 1064p. vol. 2.

WEGMULLER, U.; WERNER, C. Retrieval of vegetation parameters with SAR interferometry. IEEE Transactions on Geoscience and Remote Sensing, Piscataway, v. 35, n. 1, p. 18-24, 1997.

WULDER, M.; NIEMANN, K.; GOODENOUGH, D. Local maximum filtering for the extraction of tree locations and basal area from high spatial resolution imagery. Remote Sensing of the Environment, New York, v. 73, n. 1, p. 103-114, 2000. 